\title{
BIOPHOTONICS: ACCLIMATION OF PRE-SPROUTED SUGARCANE SEEDLINGS IN PROTECTED ENVIRONMENT
}

\author{
Luiz A. Almeida Neto ${ }^{1}$, Héliton Pandorfi²*, Alex S. Moraes ${ }^{1}$, Cristiane Guiselini ${ }^{1}$, \\ José J. Florentino C. Júnior ${ }^{3}$
}

${ }^{2 *}$ Corresponding author. Universidade Federal Rural de Pernambuco/ Recife - PE, Brasil.

E-mail: hpandorf@hotmail.com | ORCID ID: https://orcid.org/0000-0002-2037-8639

\section{KEYWORDS}

principal components, light-emitting diode, supplemental lighting, solar radiation

\begin{abstract}
Sugarcane is considered one of the main alternatives for biofuel production and an important product of Brazilian agriculture, so it is indispensable to adopt new techniques for its cultivation and management. Thus, the present study aimed to evaluate the effect of the quality of supplemental lighting, based on light-emitting diode (LED), on the acclimation of pre-sprouted sugarcane seedlings in a protected environment. The experimental design was completely randomized, consisting of three supplemental LED lighting systems, with light proportions of $90 \%$ red $+10 \%$ blue (R:B 90/10), 80\% red + $20 \%$ blue (R:B 80/20) and 70\% red $+30 \%$ blue (R:B 70/30), and a control, with natural solar radiation, with 5 replicates. Multivariate principal component analysis was used based on the matrix of correlation between all variables (meteorological, physiological and biometric). It was found that the different LED lighting systems increased the photosynthetically active radiation; however, until 20 days after planting, the seedlings were little influenced by the supplemental lighting systems. At the end of the acclimation period, the R:B 80/20 lighting system was the most associated with the growth and size of sugarcane seedlings.
\end{abstract}

\section{INTRODUCTION}

Sugarcane (Saccharum sp. L.) is an important product of Brazilian agriculture, being considered one of the main alternatives for biofuel production, and its production was 633.26 million tons in the $2017 / 18$ season, which represents a $3.6 \%$ reduction compared to the previous season. Sugarcane cultivation in the northeastern region of Brazil has been carried out since the colonial period, particularly concentrated in the coastal and Agreste regions of the states of Alagoas, Pernambuco and Paraíba (Conab, 2017; Oliveira et al., 2016).

In order for the sugarcane industry to satisfactorily meet the growing global demand for sugar and biofuels, it is necessary to increase yield and efficiency. For this, it is necessary to adopt new production systems and technologies, which can contribute to a gain yield per cultivated area. Among the new techniques, the production of pre-sprouted seedlings (PSS) emerged as an option for nursery formation, as well as replanting, renewal and expansion of sugarcane areas (Gazola et al., 2017; Marin et al., 2016).
One of the most important steps in the PSS system consists in the budding and acclimation phase, in which the seedlings remain in the protected environment, in order to minimize the adverse effects of meteorological elements. In this phase, it is possible to obtain seedlings that are more resistant and with high quality standards through the management of environmental variables.

Biophotonics is an interdisciplinary field that involves the interaction between electromagnetic radiation and biological materials, so it refers to the emission, detection, absorption, reflection and influence of photons on cells, tissues and organisms of agricultural interest. The use of artificial lighting by light-emitting diodes (LEDs) to increase the production capacity of crops in controlled environments has been considered, among the recent technologies, one of those which have great potential to optimize plant growth and make systems more efficient and sustainable (Darko et al., 2014).

LEDs can be used as a light source for production in controlled environments and as supplemental lighting in protected environments, although these applications are in early stages of development (Morrow, 2008). However,

\footnotetext{
${ }^{1}$ Universidade Federal Rural de Pernambuco/ Recife - PE, Brasil.

${ }^{3}$ Universidade Federal de Sergipe/ Nossa Senhora da Glória - SE, Brasil.

Received in: 6-20-2018
}

Accepted in: 5-8-2019 
there are few studies on the effects of lighting management on sugarcane, especially in the production of seedlings in a protected environment.

Given the above, the present study aimed to evaluate the effect of the quality of supplemental LED lighting on the acclimation of pre-sprouted sugarcane seedlings in a protected environment.

\section{MATERIAL AND METHODS}

The experiment was carried out in a protected environment located in the experimental area of the Agronomy Department of the Federal Rural University of Pernambuco, in the municipality of Recife, located in the Zona da Mata of the Pernambuco state, Brazil ( $8^{\circ} 04^{\prime}$ '03" $\mathrm{S}$; 34 $55^{\circ}$ ' $00^{\prime \prime} \mathrm{W}$; altitude of $4 \mathrm{~m}$ ). The experiment was carried out from December 2016 to January 2017.

The climate of the region is characterized as Am' megathermal, hot and humid tropical, with rains in the winter and dry season from summer to autumn, according to Köppen's classification (Alvares et al., 2013). The average annual temperature in Recife is $25.5^{\circ} \mathrm{C}$. The maximum and minimum temperatures in the region respectively occur in January, average of $27{ }^{\circ} \mathrm{C}$, and in July, average of $24{ }^{\circ} \mathrm{C}$. The protected environment used in the study is $7.0 \mathrm{~m}$ wide, $21.0 \mathrm{~m}$ long, $4.5 \mathrm{~m}$ high, with ceiling height of $3.0 \mathrm{~m}$ and covered with $150-\mu \mathrm{m}$-thick, anti-UV, low-density polyethylene film, and 50\% shade net closing the sides.

The sugarcane variety used was RB 92579, one of the three most cultivated varieties in Brazil, whose main characteristics are excellent agricultural yield, optimal budding of stubbles, good response to irrigation and water use efficiency (Ridesa, 2010).

The production and management of pre-sprouted seedlings were carried out following the methodology of the Agronomic Institute of Campinas (IAC) (Landell et al., 2012), adapted according to the conditions and resources available to conduct the experiment.

Pre-sprouted seedlings (PSS) were produced using culms from nurseries with physiological age of 6 to 10 months, which allowed greater use of the buds along the culm. Healthy buds were selected, eliminating from the process mini-cuttings with symptoms of pests, diseases and any mechanical damage to the buds. The mini-cuttings $( \pm 3 \mathrm{~cm})$ were distributed on cultivation trays, with dimensions of $6.5 \mathrm{~cm}$ height, $39 \mathrm{~cm}$ length and $27 \mathrm{~cm}$ width, covered with substrate (coconut fiber) and kept in a protected environment.

After the pre-budding period, the water and nutritional requirements of the seedlings were met by fertigation, through a sub-irrigation system, on a masonry bench with dimensions of $5.0 \mathrm{~m}$ length, $1.6 \mathrm{~m}$ width, 1.20 $\mathrm{m}$ height from soil level (upper part), $0.80 \mathrm{~m}$ height from soil level (lower part), with 7.2\% slope and 3-cm-wide edges. The substrate contained in the trays absorbed the nutrient solution by capillarity. The irrigation was automatically applied every day using a water pump connected to a timer programmed to actuate it for $15 \mathrm{~min}$.

During the acclimation period, the shoots were pruned, 20 days after planting, in order to stimulate root growth in the seedlings, as described by Landell et al. (2012).

The supplemental lighting system consisted of RGB LED bars, SYM-MT24RGB-S-BAR-24-0,52M model, in red $(640 \mathrm{~nm})$ and blue $(470 \mathrm{~nm})$ colors (Figure 1A), installed $0.5 \mathrm{~m}$ above the benches with trays, in wire frame (Figure 1B), with light flux intensity adjusted to 500 lux. The bars remained turned on for $16 \mathrm{~h}$ (12 h of natural solar radiation $+4 \mathrm{~h}$ of complementary lighting).
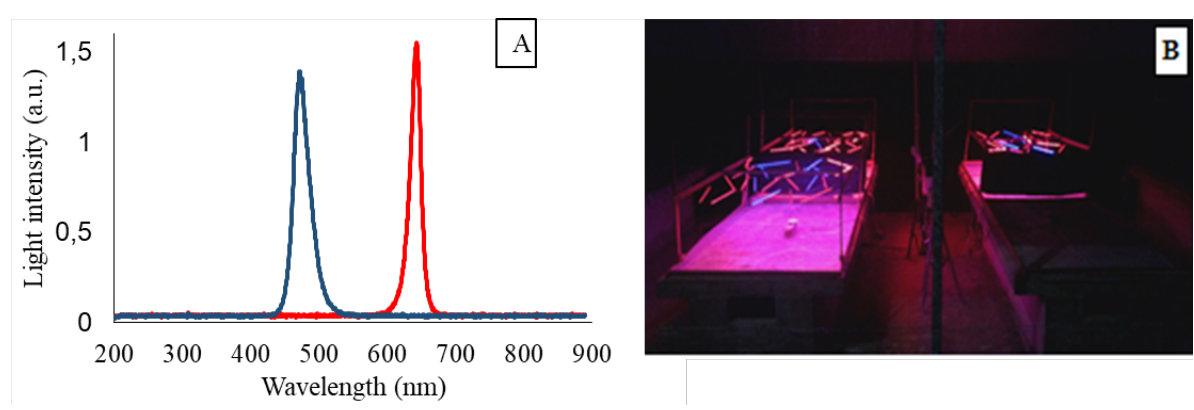

FIGURE 1. Spectral distribution of the lighting system in red and blue colors (A). View of the growing benches with the supplemental LED lighting systems installed (B)

For micrometeorological characterization inside the protected environment and in the external environment, sensors to measure air temperature (Tair, ${ }^{\circ} \mathrm{C}$ ), relative humidity $(\mathrm{RH}, \%)$, global solar radiation $\left(\mathrm{Rg}, \mathrm{MJ} \mathrm{m}^{-2}\right.$ day $^{-1}$ and $\mathrm{W} \mathrm{m}^{-2}$ ) and photosynthetically active radiation (PAR, $\mathrm{MJ} \mathrm{m}^{-2}$ day $^{-1}$ and $\mathrm{W} \mathrm{m}^{-2}$ ), connected to an automatic data logging platform, were installed at $1.50 \mathrm{~m}$ height from the floor, recorded data every second and stored the averages of the readings every $15 \mathrm{~min}$, as well as daily averages and maximum and minimum values.

The spectrum of solar radiation inside the protected environment was obtained through a spectrometer connected to a laptop with the aid of Ocean Optics SpectraSuite software.
Seedling growth was evaluated 20 days after planting and 20 days after pruning, based on the following biometric variables: plant height $(\mathrm{PH}, \mathrm{cm})$; culm length $(\mathrm{CL}, \mathrm{cm})$; culm diameter $(\mathrm{CD}, \mathrm{cm})$; number of leaves $(\mathrm{NL})$; leaf width and leaf length (LW and LL, cm); and root length (RL, cm).

Leaf area (LA) was determined using [eq. (1)]:

$$
\mathrm{LA}=\mathrm{L} \times \mathrm{W} \times 0.75(\mathrm{~N}+2)
$$

Where,

$$
\begin{aligned}
& \text { L - leaf length }(\mathrm{cm}) ; \\
& \text { W - leaf width }(\mathrm{cm}) \text {, } \\
& \mathrm{N} \text { - number of leaves. }
\end{aligned}
$$


Root volume $\left(\mathrm{RV}, \mathrm{mm}^{3}\right)$ was obtained at the end of the acclimation period, based on the displacement of water volume in a graduated cylinder. The root system and the shoots were placed in an oven at $60^{\circ} \mathrm{C}$ for $72 \mathrm{~h}$ and then the material was weighed to determine the dry mass of shoots (SDM, g) and roots (RDM, g).

The contents of total soluble carbohydrates and sucrose were determined according to the methodology described by Bezerra Neto \& Barreto (2011), in which a curve was obtained with a standard glucose solution for the total soluble carbohydrate content and another curve with a sucrose standard solution for sucrose content at the respective concentrations of $25,50,100$, and $200 \mathrm{mg} \mathrm{L}^{-1}$.

The experimental design was completely randomized, with three supplemental lighting systems, in which the proportions of light were $90 \%$ red $+10 \%$ blue (R:B 90/10), $80 \%$ red $+20 \%$ blue (R:B 80/20), $70 \%$ red + $30 \%$ blue (R:B 70/30) and control (natural solar radiation), with 5 replicates, each of which consisting of 50 trays of 15 cells, totaling 750 seedlings.
Meteorological data recorded in the external environment and inside the protected environment were analyzed using linear regressions. The regressions were subjected to $F$ test to evaluate their significance.

The association between the biometric, physiological and meteorological variables was evaluated by multivariate principal component analysis, based on the matrix of correlation between all variables, using the computer programs Minitab $^{\circledR}$ and Origin $^{\circledR}$, as well as graphic representations. The data subjected to multivariate analysis were previously standardized because there is large variation due to the magnitude of the various variables.

\section{RESULTS AND DISCUSSION}

Figure 2 shows the daily variation of the average air temperature obtained in the protected environment (internal Tair) and in the external environment (external Tair). Along the entire experimental period, the internal Tair was higher than the air temperature observed in the open sky.

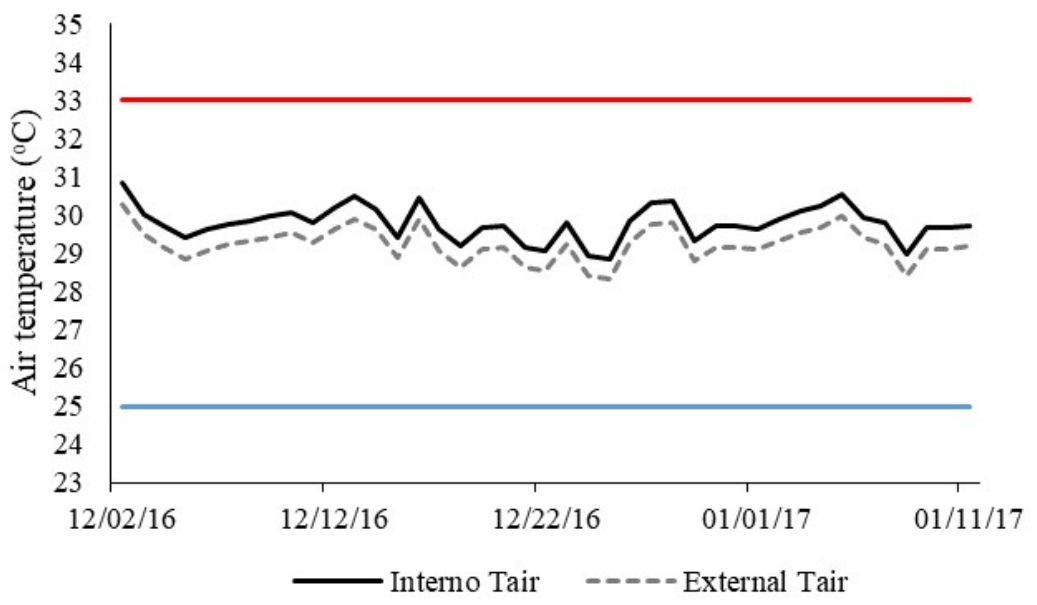

FIGURE 2. Daily variation of the average air temperature inside the protected environment and in the external environment along the experimental period.

The average air temperature inside the protected environment was $29.78{ }^{\circ} \mathrm{C}$, which is within the range (25$33{ }^{\circ} \mathrm{C}$ ) considered favorable to the vegetative development of the crop (Almeida et al., 2008). Guerra et al. (2014), evaluating the effect of air temperature on photosynthesis in the initial stage of sugarcane growth in a climatecontrolled chamber, concluded that high air temperature $\left(33{ }^{\circ} \mathrm{C}\right.$ during the day and $27^{\circ} \mathrm{C}$ at night) did not affect the photosynthetic efficiency of sugarcane.

The difference in air temperature inside the environment was of $1.23{ }^{\circ} \mathrm{C}$, compared to the external environment, which is expected due to the reduction in the convective process caused by the cover of the protected environment, which limits air renewal. Andrade Júnior et al. (2011) found a $2.3{ }^{\circ} \mathrm{C}$ increase in the average air temperature inside the protected environment in October. Guiselini et al. (2013) observed, in the municipality of Igarassu, PE, an average air temperature inside the protected environment of $0.44{ }^{\circ} \mathrm{C}$, above the one recorded in the external environment.

Air temperature inside the protected environment in the acclimation of sugarcane seedlings is directly related to the growth and photosynthetic processes of the plants, besides allowing recently sprouted plants to express their potential without being affected by any sort of stress. According to Jadoski et al. (2012), air temperature interferes with the speed of biochemical reactions and the action of enzymes involved in cell division, differentiation and growth.

It can be observed in Figure 3 that the mean RH value in the protected environment was lower than that in the external environment, 69.03 and $70.71 \%$, respectively. It is possible to find in the literature other studies which found that, in protected environments, $\mathrm{RH}$ is lower than the values obtained under external conditions, as observed by Andrade Júnior et al. (2011), who verified that the RH in the protected environment was, on average, $3.2 \%$ lower than that in the external environment. Likewise, Andrade et al. (2011) observed variations between 46.7 and $82.4 \%$ in a protected environment covered with light-diffusing thermal film, between 47.2 and $82.6 \%$ in protected environment covered with conventional polyethylene film, and between 41.0 and $81.8 \%$ in open field. 


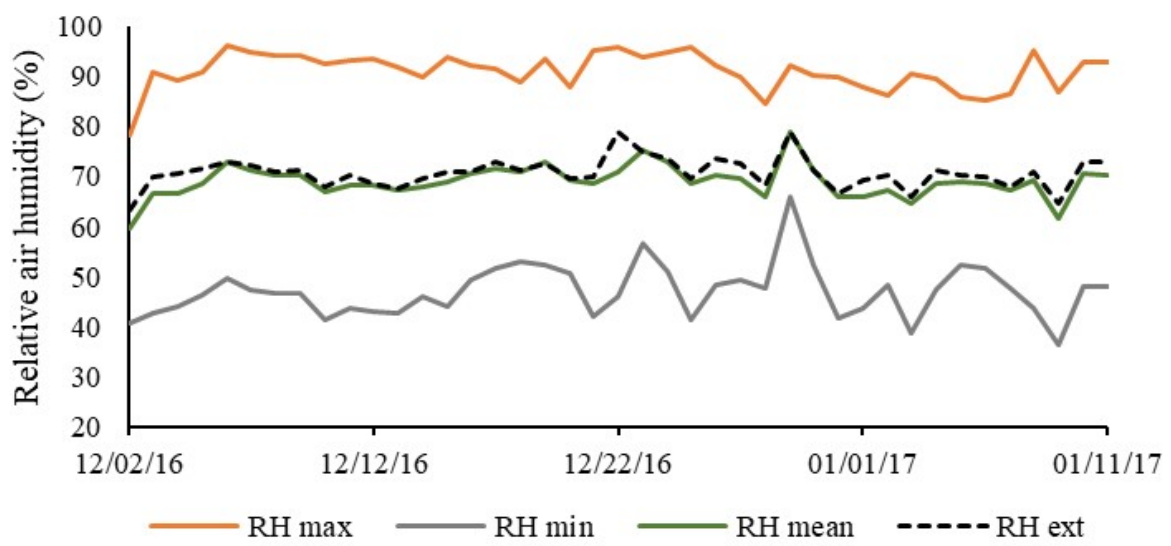

FIGURE 3. Daily variation of relative air humidity, maximum, mean and minimum in the protected environment and in the external environment along the experimental period.

There was a peak in RH occurred on December 29, with the highest values in the protected environment $(79 \%)$ and in the external environment $(78.75 \%)$, which can be attributed to the minimum thermal amplitude recorded in the period (Figure 2), of $5.31{ }^{\circ} \mathrm{C}$ in the protected environment and $4.23{ }^{\circ} \mathrm{C}$ in the external environment. In the production of pre-sprouted sugarcane seedlings, the control of relative humidity has the function of minimizing the effect of high air temperatures.
According to Figure 4, along the entire period, the global solar radiation observed in the protected environment was lower than that recorded in the external environment (19.36 $\mathrm{MJ} \mathrm{m}^{-2}$ day $^{-1}$ ). Ferreira Junior et al. (2012), in the state of Alagoas, observed daily average incident $\mathrm{Rg}$ of $20.9 \mathrm{MJ} \mathrm{m}^{-2}$ up to 70 days after the sugarcane cut. André et al. (2010), studying the development of sugarcane throughout its cycle, observed global solar radiation of $20.36 \mathrm{MJ} \mathrm{m}^{-2}$ in the culm development stage.

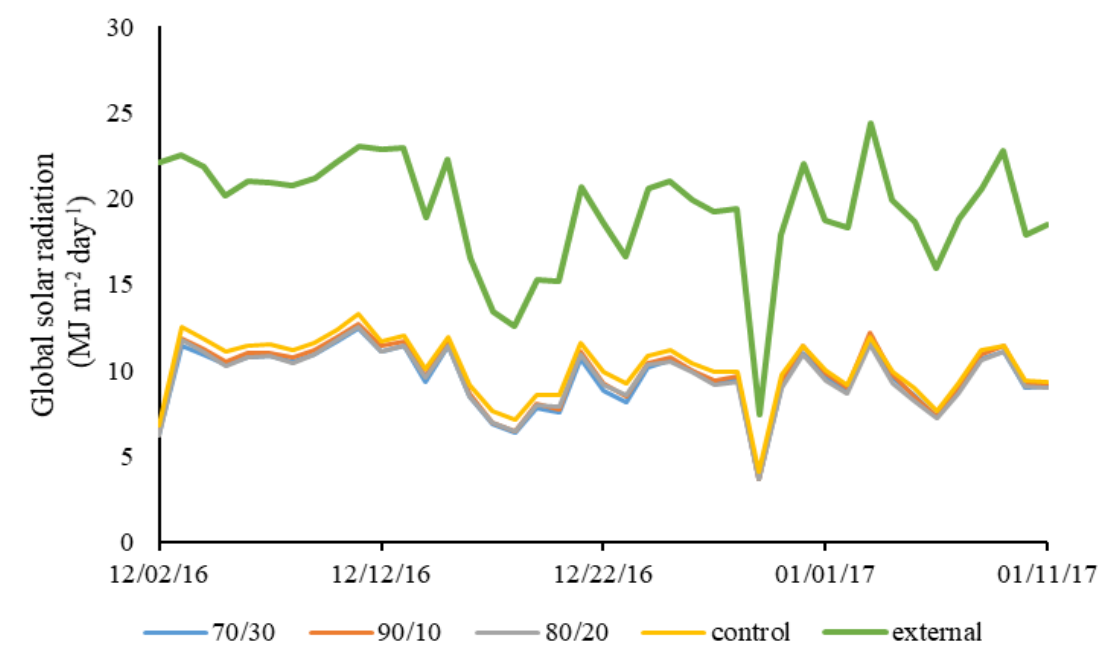

FIGURE 4. Variation of global solar radiation in the studied treatments in the protected environment and in the external environment along the experimental period

The differences between the supplemental lighting systems R:B 70/30, R:B 90/10, R:B 80/20 and control, compared to the external environment, were $9.55,9.79$, 9.56, $10.17 \mathrm{MJ} \mathrm{m}^{-2} \mathrm{day}^{-1}$, respectively. This reduction occurs due to the attenuation promoted by reflection and absorption of radiation by the plastic cover. Ferrari \& Leal (2015) obtained an average global solar radiation of 9.2

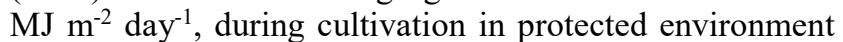
covered with low-density polyethylene (LDPE) associated with a thermo-reflective net, in the municipality of Rio das Pedras-SP. Cordeiro Júnior et al. (2019), evaluating different photo-selective nets in the acclimation of sugarcane seedlings in a protected environment, covered with anti-UV LDPE, in the municipality of Recife, found global solar radiation of $10.68 \mathrm{MJ} \mathrm{m}^{-2}$ day $^{-1}$. By comparing the mean values of $\mathrm{Rg}$ for the lighting systems, it is possible to note differences in relation to the control of 0.62 (R:B 70/30), 0.38 (R:B 90/10) and 0.60 (R:B 80/20). Despite being very similar, these values did not contribute to the increase of $\mathrm{Rg}$ inside the protected environment.

It can be observed in Figure 5 that the coefficients of determination were high $\left(\mathrm{R}^{2}>0.92\right)$, which demonstrates the strong relationship of proportion between the variation of solar radiation in the external environment and the lighting systems. 

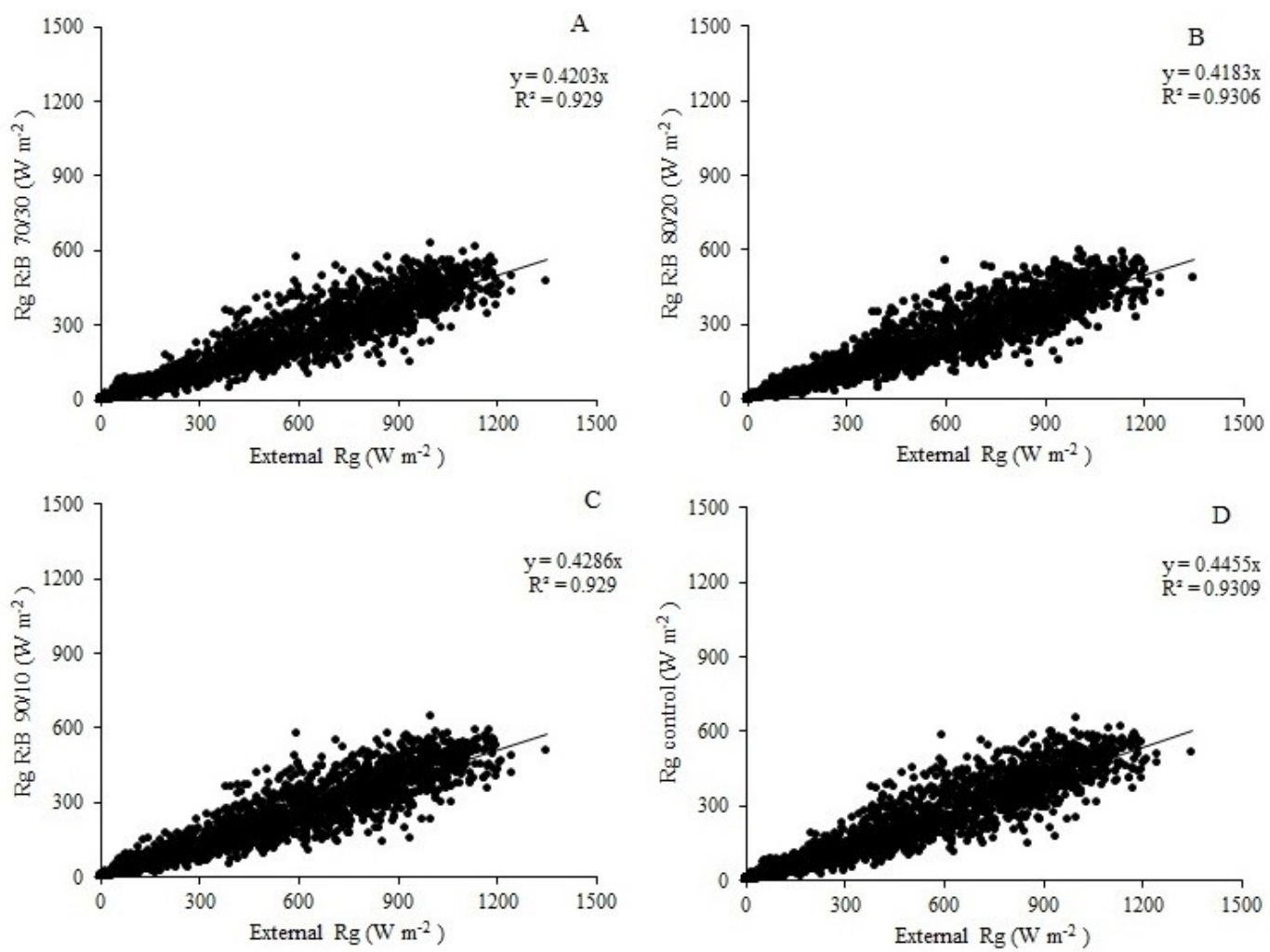

FIGURE 5. Relationships between the global solar radiation observed in the external environment and under the lighting systems inside the protected environment along the experimental period: R:B 70/30 (A); R:B 90/10 (C); R:B 80/20 (B) and control (D).

The transmittance in the lighting systems $\mathrm{R}: \mathrm{B}$ 70/30, R:B 90/10, R:B 80/20 and control was 42, 42, 41 and $44 \%$, respectively. It is possible to note that the values of transmittance were very similar in the supplemental lighting systems, but the control had the highest availability of energy. This difference between the observed transmittance may have been caused by the structure in which the LEDs were installed. According to Dal Pai et al. (2013), for the same value of external global radiation, there can be many values of internal global radiation, which increases the dispersion and decreases the correlation between the two radiations in the linear regression.
It can be seen in Figure 6 that, unlike the observed in $\mathrm{Rg}$ distribution, the PAR measured under the lighting systems (R:B 70/30; R:B 90/10; R:B 80/20) had mean values $\left(3.44,3.68,3.67 \mathrm{MJ} \mathrm{m}^{-2}\right.$ day $^{-1}$ ) higher than that observed under the control $\left(2.61 \mathrm{MJ} \mathrm{m}^{-2}\right.$ day $\left.^{-1}\right)$, during the entire period. Hence, it can be stated that the supplemental lighting systems contributed to the increase of PAR. Elli et al. (2016) found that the reduction in the amount of incident PAR in the understory of agroforestry systems caused alterations in the thermal and physiological characteristics of sugarcane.

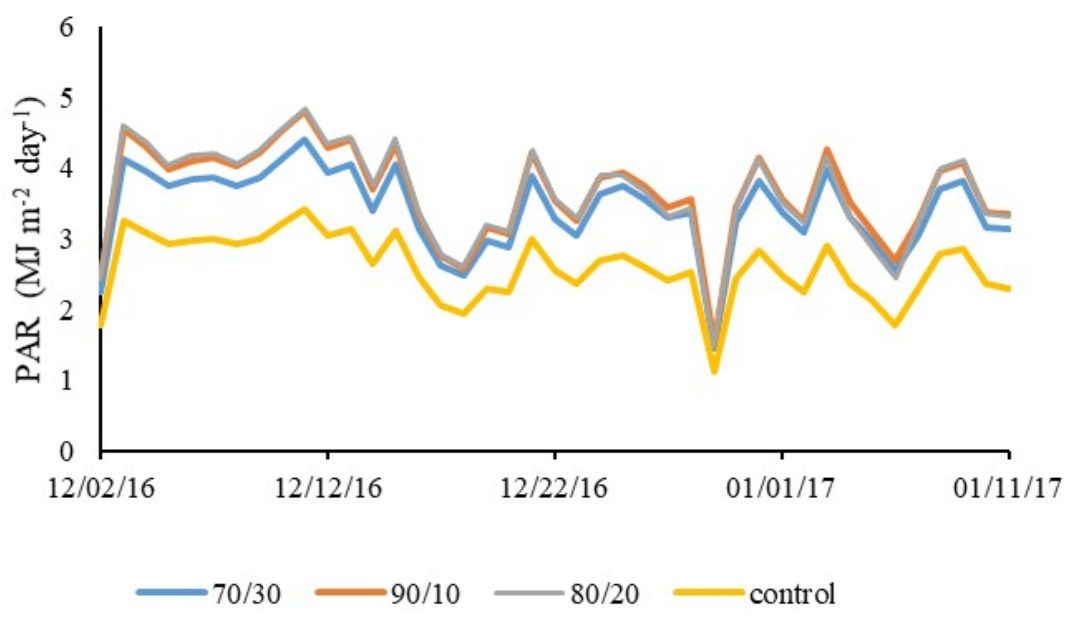

FIGURE 6. Variation of photosynthetically active radiation (PAR) in each of the treatments studied. 
Figure 7 shows that, in all LED lighting systems, there is a significant increase in the red $(620-700 \mathrm{~nm})$ and blue (450-495 nm) bands compared to the control. The use of supplemental lighting changed the distribution of the violet $(400-450 \mathrm{~nm})$, yellow $(570-590 \mathrm{~nm})$ and orange (590-620 nm) wavelengths. However, for the green wavelength range, the control showed a higher percentage
$(37.66 \%)$. The results highlight the characteristic of the LEDs of having specific wavelength (Yeh \& Chung, 2009), which differentiates them from other sources of light. LEDs are suitable for light supplementation because of their versatility and ease to combine wavelengths (Maluta et al., 2013). Souza et al. (2011) state that, in addition to the intensity, the quality of the radiation is determinant for the development of the plant cells.

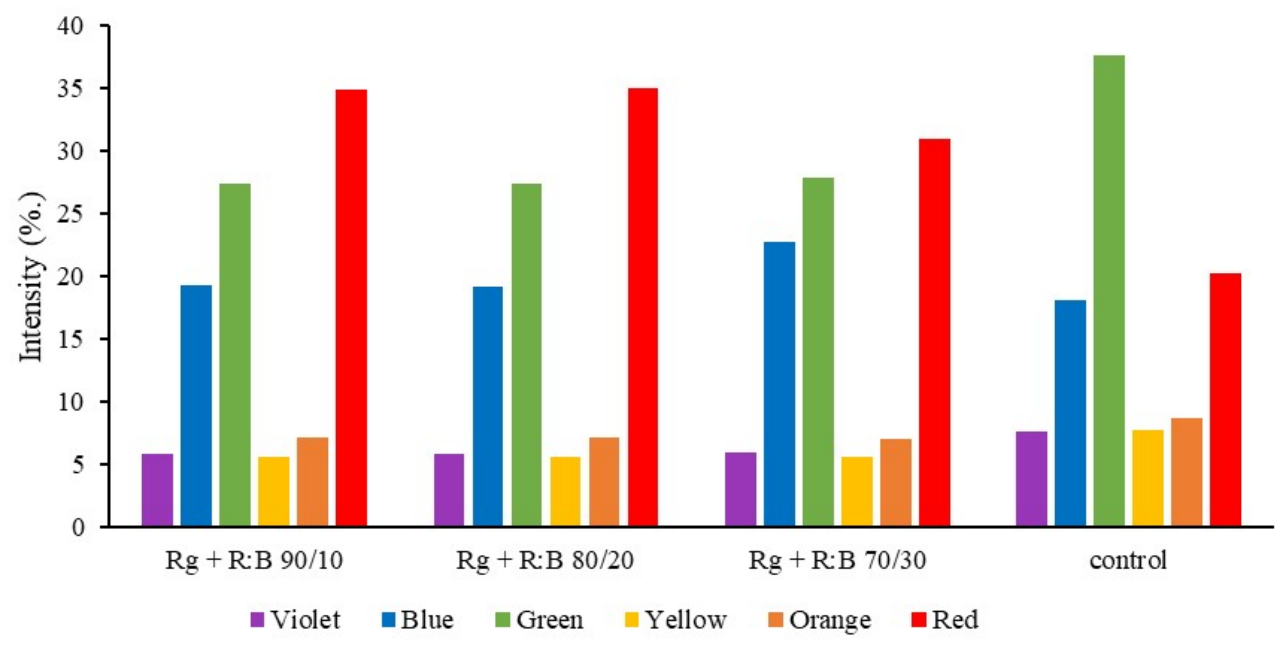

FIGURE 7. Spectral distribution of the LED lighting systems and control.

Figure $8 \mathrm{~A}$ shows that $77 \%$ of the original variability was explained by the first two principal components (PC1 and PC2), which retained 48 and 29\%, respectively, of the original information of the data. Similar results were found by Leite et al. (2016), who aimed to select soybean genotypes with superior agronomic traits through multivariate exploratory analysis and observed that, in the principal component analysis, two eigenvalues explained $68.17 \%$ of the variance contained in the original information, generating two components with relevant amounts of information. Noronha (2018), evaluating the monthly vegetative growth of sugarcane, through biometric parameters, in three soil management systems and two varieties of sugarcane propagated by pre-sprouted seedlings, observed that the two principal components explained $78 \%$ of the variability contained in the original information.
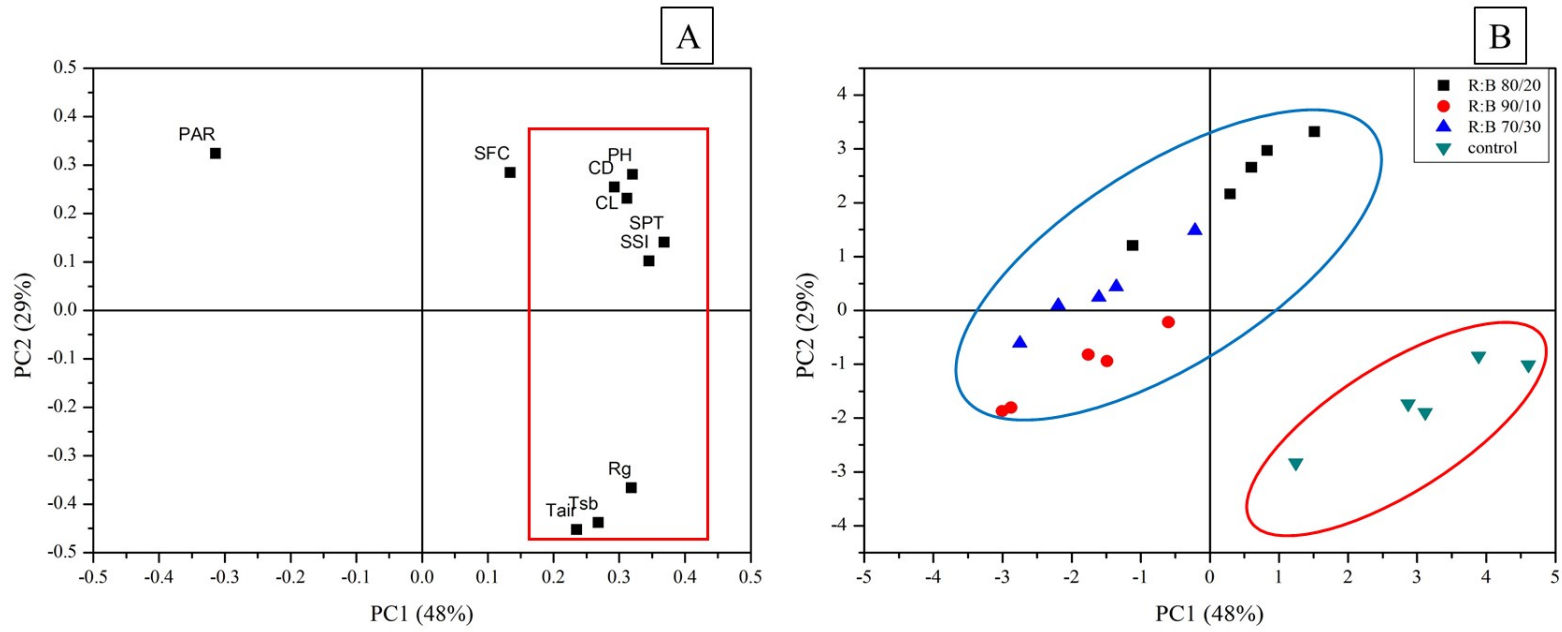

FIGURE 8. Principal component analysis of biometric and micrometeorological variables for each lighting system until 20 DAP. Coefficients (A) and scores (B).

$\mathrm{Rg}=$ global solar radiation; $\mathrm{Tsb}=$ temperature of substrate; Tair $=$ air temperature; $\mathrm{SSI}=$ sprouting speed index; $\mathrm{SPT}=$ sprouting percentage; $\mathrm{CL}=$ culm length $\mathrm{CD}=$ culm diameter; $\mathrm{PH}=$ plant height; $\mathrm{SFC}=$ sprouting first count; $\mathrm{PAR}=$ photosynthetically active radiation 
It can be observed that Tair and Tsb are grouped with $\mathrm{Rg}$, which was already expected due to the high correlation between the greater availability of solar radiation and Tair, consequently leading to higher values of Tsb (Figure 8A). Air temperature interferes with plant cell growth and is considered one of the variables that most influence the sprouting (Jadoski et al., 2012). It can be noted that the biometric variables of the seedlings $(\mathrm{PH}$, $\mathrm{CD}$ and $\mathrm{CL}$ ) are related to the sprouting percentage (SPT) and sprouting speed index (SSI) (Figure 8).

According to Figure $8 \mathrm{~B}$, there is a clear separation between the LED lighting systems (R:B 80/20, R:B 90/10, $\mathrm{R}: \mathrm{B} 70 / 30$ ) and the control. It is understood that this grouping was characterized by the difference between PAR and Rg. However, similarity was found between the lighting systems, especially between R:B 90/10 and R:B $70 / 30$, which are more associated with the variable PAR, but were less associated with the biometric variables. Among the LED systems, the one with highest association with the biometric variables was R:B 80/20. The responses of plants to the spectral quality depend on complex processes that involve combined actions of the photoreceptors and vary according to development stage and plant species.

The variations found in the present study indicate that, until 20 DAP, the variables related to sprouting (SPT and SSI) were more significant for the biometric responses $\mathrm{PH}, \mathrm{CD}, \mathrm{CL}$ than the different LED lighting systems. According to Manhães et al. (2015), besides the environmental factors, other factors such as variety, age and health of gems, and the management adopted in planting may affect the sprouting process. In the budding stage, it is understood that solar radiation has little effect on the development of sugarcane buds.

During the initial period of sugarcane sprouting, the nutritional reserves contained in the cuttings are fundamental for the evolution of the process, which becomes less dependent as the root system and shoots of the plant develop (Manhães et al., 2015). It can be understood that the different LED lighting systems have little influence during this period due to the low photosynthetic activity. In a study evaluating the use of different reflective materials in growing benches, Santos et al. (2017) observed that the physical conditions of reflectance of the tested materials did not influence the emergence speed index of passion fruit, although the materials showed different results of reflected photosynthetically active radiation.

Figure 9 shows the percentage of variance explained by the principal components PC1 and PC2, which are 33 and $22 \%$, respectively. Figure $9 \mathrm{~B}$ shows that PC2 was responsible for the formation of two distinct groups among the LED lighting systems (R:B 80/20, R:B 90/10, R:B 70/30) and the control. The control is located in the upper portion of the chart, whereas the LED lighting systems are in the lower portion. Figure 9A highlighted that the main responsible for the observed grouping are the variables $\mathrm{Rg}$ and $\mathrm{TCH}$, which are located in the upper part of the chart, and the variable PAR, in the negative part of the graph of coefficients. From the physical point of view, this difference may be related to the greater availability of PAR under the LED lighting systems. It is also possible to note the correlation of the physiological variables $\mathrm{TCH}$ and SUC with Rg.
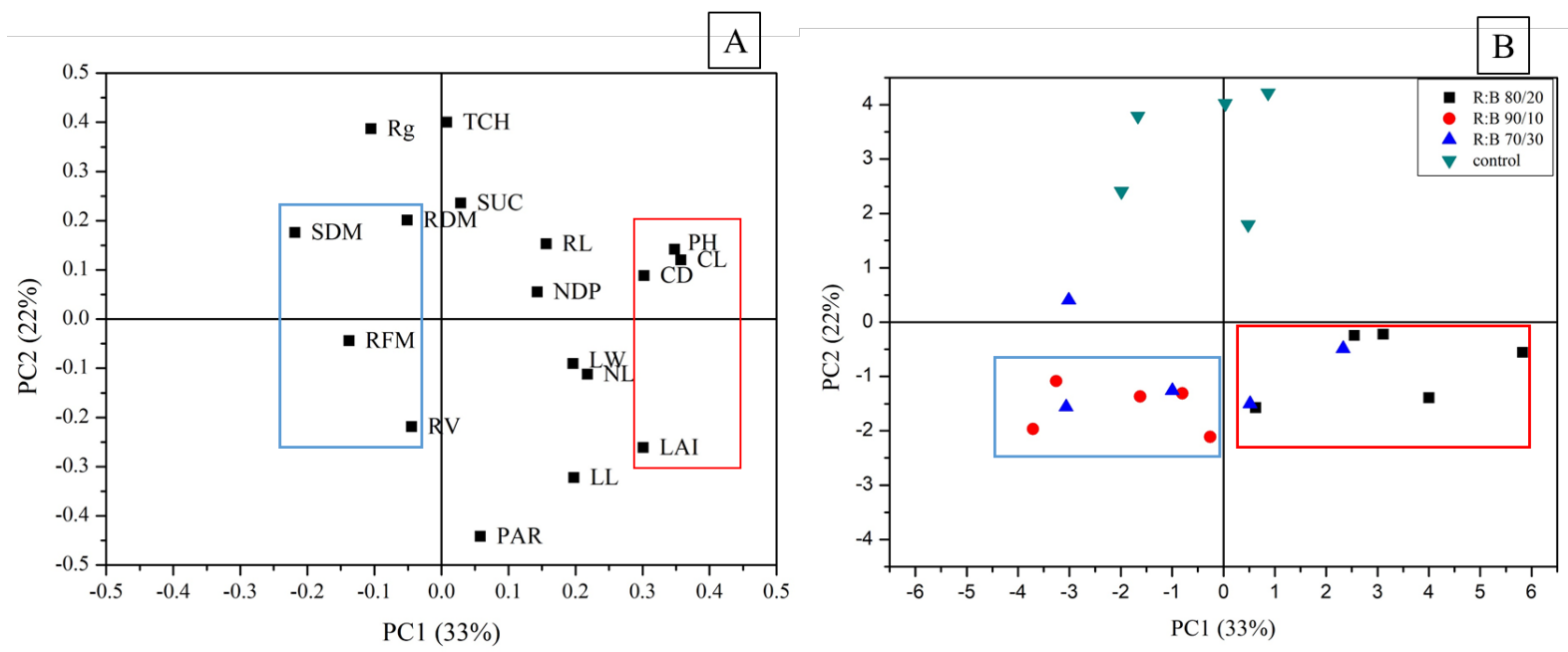

FIGURE 9. Principal component analysis of biometric and micrometeorological variables for each lighting system at 40 DAP. Coefficients (A) and scores (B).

$\mathrm{Rg}=$ global solar radiation; $\mathrm{PAR}=$ photosynthetically active radiation; $\mathrm{CL}=$ culm length; $\mathrm{CD}=$ culm diameter; $\mathrm{PH}=$ plant height; $\mathrm{LAI}$ : leaf area index; NL = number of leaves; $\mathrm{LL}=$ leaf length; $\mathrm{LW}=$ leaf width; NDP = number of dead plants; RL = root length; SUC = sucrose content; $\mathrm{TCH}=$ total carbohydrate content; $\mathrm{RDM}=$ root dry matter; RV = root volume; RFM = root fresh matter; $\mathrm{SDM}=$ shoot dry matter 
It is possible to see a separation of the LED lighting system R:B 80/20 from the others, and the variables that most contributed to this distinction were: $\mathrm{CL}, \mathrm{PH}, \mathrm{CD}$ and LAI (Figure 9A). Ferreira et al. (2016) observed that plants exposed to LED showed higher averages for shoot height and number of leaves, compared to plants cultivated under fluorescent lamps. Silva et al. (2014) evaluated different combinations of LED light on sugarcane, cultivated in vitro, and found higher values of plant height when subjected to treatment Red/Blue proportion of $70 / 30 \%$. However, for the number of leaves, in the present study, the highest values were found in the treatments with higher proportions of blue.

Although they have less influence, by analyzing PC1 it is possible to observe that the variables RL and NDP also contribute to the grouping characterized by the R:B 80/20 system.

The group formed by the R:B 90/10 system was more correlated with the variables SDM, RFM, RDM and RV. Maluta et al. (2013) observed higher values of dry matter in plants grown under lighting with higher proportions of red (100\% and R:B 70/30\%). This relationship contrasts with the results reported by Silva et al. (2014), who observed greater association between the total fresh weight of sugarcane plants and treatments with higher proportion of blue light $(70 \%)$. According to Maluta et al. (2013), little is known about the response of sugarcane when exposed to different light sources, which highlights the importance of evaluating the effects of possible combinations of LEDs on seedling size.

\section{CONCLUSIONS}

The use of supplemental lighting based on LED light inside the protected environment increased the photosynthetically active radiation along the acclimation period.

Increment in blue and red wavelengths promoted by the supplemental lighting systems showed little influence on the sprouting and biometric variables, until 20 days after planting the pre-sprouted sugarcane seedlings.

The R:B 80/20 lighting system was the most associated with the biometric variables of the seedlings, at the end of the acclimation period.

\section{REFERENCES}

Almeida ACS, Souza JL, Teodoro I, Barbosa GVS, Moura Filho G, Ferreira Júnior RA (2008) Desenvolvimento vegetativo e produção de variedades de cana-de-açúcar em relação à disponibilidade hídrica e unidades térmicas. Ciência e Agrotecnologia 32(5):1441-144. DOI: https://dx.doi.org/10.1590/S1413-70542008000500013

Alvares CA, Stape JL, Sentelhas PC, Gonçalves JLM, Sparovek G (2013) Köppen's climate classification map for Brazil. Meteorologische Zeitschrift 22(6):711-728. DOI: https://doi.org/10.1127/0941-2948/2013/0507

Andrade JWDS, Farias Júnior M, Sousa MAD, Rocha AC (2011) Utilização de diferentes filmes plásticos como cobertura de abrigos para cultivo protegido. Acta Scientiarum. Agronomy 33(3):437-443. DOI: https://dx.doi.org/10.4025/actasciagron.v33i3.2784
Andrade Júnior AS, Damasceno LMO, Dias NS, Gheyi HR, Guiselini C (2011) Climate variations in greenhouse cultivated with gerbera and relationship with external conditions. Engenharia Agrícola 31(5):857-867. DOI: http://dx.doi.org/10.1590/S0100-6916201100 0500003

André RGB, Mendonça JC, Marques VDS, Pinheiro FMA, Marques J (2010) Aspectos energéticos do desenvolvimento da cana-de-açúcar. Parte 1: balanço de radiação e parâmetros derivados. Revista Brasileira de Meteorologia 25(3):375-382. DOI: https://dx.doi.org/ 10.1590/S0102-77862010000300009

Bezerra Neto E, Barreto LP (2011) Análises químicas e bioquímicas em plantas. Recife, Ed. Universitária da UFRPE, p161.

CONAB - Companhia Nacional de Abastecimento (2017) Acompanhamento da safra brasileira cana-de-açúcar safra 2017/2018, 2(4). CONAB. Available at: http://www.conab.gov.br/OlalaCMS/ uploads/arquivos/18_01_08_09_08_38_cana_dezembro_n ovo.pdf. Accessed: Jan 12, $201 \overline{7}$.

Cordeiro Júnior JJ, Pandorfi H, Barbosa Filho JA, Moraes AS, Almeida Neto LA, Guiselini C (2019) Photo-selective shade nets on the production and quality of sugarcane plantlets. Revista Brasileira de Engenharia Agrícola e Ambiental 23(5):366-371. DOI:

http://dx.doi.org/10.1590/1807-1929/agriambi.v23n5p366-371

Dal Pai E, Escobedo JF, Martin D (2013) Radiações UV, PAR e IV em estufa de polietileno. Revista Brasileira de Energia Solar 4(1):01-08.

Darko E, Heydarizadeh P, Schoefs B, Sabzalian MR (2014) Photosynthesis under artificial light: the shift in primary and secondary metabolism. Philosophical Transactions of the Royal Society B: Biological Sciences 369(1640). DOI:

http://dx.doi.org/10.1098/rstb.2013.0243

Elli EF, Caron BO, De Paula GM, Eloy E, Schwerz F, Schmidt, D (2016) Ecophysiology of sugarcane in the understory of Peltophorum dubium Spr. in agroforestry systems arrangements. Comunicata Scientiae 7(4):464472. DOI: https://doi.org/10.14295/cs.v7i4.1538

Ferrari DL, Leal PAM (2015) Uso de tela termorrefletora em ambientes protegidos para cultivo do tomateiro. Engenharia Agrícola 35(2):180-19. DOI: http://dx.doi.org/10.1590/1809-4430-

Eng.Agric.v35n2p180-191/2015

Ferreira LT, Araújo Silva MM, Macêdo CR, Willadino L (2016) Fonte de luz e concentração de sacarose no cultivo in vitro da cana-de-açúcar (RB 867515). Plant Cell Culture \& Micropropagation 12(2):46-52.

Ferreira Junior RA, Souza JLD, Lyra GB, Teodoro I, Santos MAD, Porfirio A (2012) Growth and photosynthesis of sugarcane based on biometric and meteorological variables. Revista Brasileira de Engenharia Agrícola e Ambiental 16(11):1229-1236 DOI: http://dx.doi.org/10.1590/S1415-43662012001100012 
Gazola T, Cipola Filho ML, Franco Júnior NC (2017)

Avaliação de mudas pré-brotadas de cana-de-açúcar provenientes de substratos submetidos a adubação química e orgânica. Científica 45(3):300-306. DOI:

http://dx.doi.org/10.15361/1984-5529.2017v45n3p300-306

Guiselini C, Pandorfi H, Barros AC, Silva LF, Silva Neto SP (2013) Aclimatização de mudas de cana-de-açúcar em ambiente protegido sob dois tipos de malhas de sombreamento. Revista Brasileira de Engenharia Agrícola e Ambiental 17(8):877-882. DOI: http://dx.doi.org/10.1590/S1415-43662013000800012

Jadoski CJ, Toppa EVB, Rodrigues JD (2012)

Desenvolvimento morfofisiológicos de raízes e brotos da cana-de-açúcar (Saccharum Officinarum L.). Scientia Agraria Paranaenis 11(2):22-32. DOI:

http://dx.doi.org/10.1818/sap.v11i2.4563

Landell MG, Campana MP, Figueiredo P, Xavier MA, Anjos IA, Dinardo-Miranda LL, Scarpari MS, Garcia JC, Bidóia MAP, Silva DN, Mendonça JR, Kanthack RAD, Campos MF, Brancalião SR, Petri RH, Miguel PEM (2012) Sistema de multiplicação de cana-de-açúcar com uso de mudas pré-brotadas (MPB), oriundas de gemas individualizadas. Ribeirão Preto, Instituto Agronômico de Campinas, p16. (Documento IAC 109).

Leite WDS, Pavan BE, Alcantara Neto F, Matos Filho CHA, Feitosa FS, Oliveira CB (2016) Multivariate exploratory approach and influence of six agronomic traits on soybean genotypes selection. Nativa 4(4):206-210. DOI: http://dx.doi.org/10.14583/2318-7670.v04n04a04

Manhães CMC, Garcia RF, Francelino FMA, Francelino HO, Coelho FC (2015) Fatores que afetam a brotação e o perfilhamento da cana-de-açúcar. Vértices 17(1):163-181. DOI: http://dx.doi.org/10.5935/1809-2667.20150011

Maluta FA, Bordignon SR, Rossi ML, Ambrosano MB, Rodrigues PHV (2013) Cultivo in vitro de cana-de-açúcar exposta a diferentes fontes de luz. Pesquisa agropecuária brasileira 48(9):1303-1307. DOI: http://dx.doi.org/10.1590/S0100-204X2013000900015
Marin FR, Martha GB, Cassman KG, Grassini P (2016) Prospects for increasing sugarcane and bioethanol production on existing crop area in Brazil. BioScience 66(4):307-316. DOI: https://doi.org/10.1093/biosci/biw009

Morrow RC (2008) LED lighting in horticulture. HortScience 43(7):1947-1950.

Noronha RHF (2018) Plantio de mudas pré brotadas (MPB) de cana de açúcar em sistemas de manejo conservacionista de solo. Tese Doutorado, Jaboticabal, Universidade Estadual Paulista.

Oliveira AR, Braga MB, Santos BLS, Walker AM (2016) Análise biométrica de cultivares de cana-de-açúcar cultivadas sob estresse hídrico no vale do submédio São Francisco. Energia na Agricultura 31(1):48-58. DOI: http://dx.doi.org/10.17224/EnergAgric.

2016v31n1p48-58

RIDESA - Rede Interuniversitária para o Desenvolvimento do Setor Sucroalcooleiro (2010) Catálogo nacional de variedades "RB" de cana-de-açúcar. RIDESA, $136 \mathrm{p}$.

Santos TV, Lopes TC, Silva AG, Paula RCM, Costa E, Binotti FFS (2017) Produção de mudas de maracujá amarelo com diferentes materiais refletores sobre bancada. Revista de Agricultura Neotropical 4(4):26-32.

Souza GS, Castro EM, Soares ÂM, Santos AR, Alves E (2011) Photosynthetic pigments content, photosynthesis rate and chloroplast structure in young plants of Mikania laevigata Schultz Bip. ex Baker grown under colored nets. Semina: Ciências Agrárias 32(4):1843-1854. DOI: http://dx.doi.org/10.5433/16790359.2011v32n4Sup1p1843

Yeh N, Chung JP (2009) High-brightness LEDs - Energy efficient lighting sources and their potential in door plant cultivation. Renewable and Sustainable Energy Reviews 13(8):1-6. DOI: https://doi.org/10.1016/j.rser.2009.01.027 